\title{
Factor-Based Quantitative Comparison Analysis of the Inheritance of Intangible Cultural Heritage: A Case Study of Kunqu Opera between Chinese Mainland and Taiwan
}

\author{
Run Zhao ${ }^{1} \&$ Yasufumi Uekita ${ }^{2}$ \\ ${ }^{1}$ Doctoral Program in Heritage Studies, University of Tsukuba, Japan \\ ${ }^{2}$ Faculty of Art and Design, University of Tsukuba, Japan \\ Correspondence: Run Zhao, Heritage Studies, University of Tsukuba, Cooperative Research Building A-204, \\ Tennodai 1-1-1, Tsukuba City, 305-8577, Japan. Tel: 080-9878-5237. E-mail: congrong4suo@hotmail.com
}

Received: June 5, 2020

Accepted: July 1, $2020 \quad$ Online Published: September 30, 2020

doi:10.5539/ach.v12n1p23

URL: https://doi.org/10.5539/ach.v12n2p23

\begin{abstract}
In 1940s, the Kuomintang (KMT) retreated to Taiwan, along with a lot of amateur artists accomplished in singing and dancing of Kunqu Opera. Due to unlike and separate social environments, Kunqu Opera developed into two different ways in Taiwan and Chinese mainland since then. In contrast with Taiwan's choice to maintain the tradition of Kunqu Opera, especially that of 1930s as much as possible, Chinese mainland turns to modernize this art to cater to social trends. This paper analyses two versions of the same scene "Broken Bridge" (断桥) from Taiwan and Chinese mainland in spoken language, melody, literary form of lyrics, dance, stage set and costumes to try to find the factors that are not changed, which can be understood as the core factors with inherited cultural values of the intangible cultural heritage. Based on these core factors, the effective protection is possible. This research shows that although Kunqu Opera in Chinese mainland is gradually changing, particularly turning realistic as opposed to the one keeping impressionistic in Taiwan, there are some factors almost untransformed: the melody (kunqiang), literary form of lyrics (qupai style), costumes evolving from the dress of Ming dynasty. An effective protection method of Kunqu Opera should put emphasis on these factors.
\end{abstract}

Keywords: Intangible Cultural Heritage, Factor-Based Quantitative Comparison Analysis, Inheritance, Kunqu Opera, Core Factors

\section{Introduction}

As a constantly changing heritage, the intangible cultural heritage is always considered as lack of authenticity, however, the changing is always based on several rules, which means even though other factors are changing, the core factors are remained as inherited cultural values all the time. And protection measures based on these core factors will be effective. However, partly because of difficulties to record intangible cultural heritage and the insufficiency of records, discussions about it from heritage angle are deficient in former researches. In this paper, China's intangible cultural heritage Kunqu Opera is taken as an example, Chinese mainland's modern style and Taiwan's classical style, which have the same roots but evolve towards divergent directions as a result of isolation and recommunication of the two areas, will be compared in spoken language, melody, literary form of lyrics, dance, stage set and costumes to find out core factors that are not changed even in different social environments till now. Factor-based quantitative comparison analysis will be applied to judge the core factors of this art. Specifically, the opera factors in two different versions of the same scene "Broken Bridge" (断桥) from Chinese mainland and Taiwan will be compared.

China's Kunqu Opera, as a typical ancient stage performing art, was inscribed in 2008 on UNESCO's Representative List of the Intangible Cultural Heritage of Humanity (originally proclaimed as one of the Masterpieces of the Oral and Intangible Heritage of Humanity in 2001). With a history of more than 400 years since its debut as an opera sung with kunqiang (昆腔), also called Shuimoqiang (水磨腔), a kind of soft melody created by musician Wei Liangfu (魏良辅) in the mid-16th century, this art has a colossal implication for a variety of operas including Peking opera and Sichuan opera. Thanks to its elegance in music and lyrics, among other reasons, Kunqu Opera once became a popular opera nationwide, especially appealing to elites. However, after more than 100-year long prosperity in China, Kunqu Opera has long been suffering a decline since 18th century. 
Because of its prominent position in China's opera history, adequate analysis and effective protection of Kunqu Opera are advantageous not only to itself but also to other Chinese operas.

During the theatre reform campaign from 1949 (the year the People's Republic of China was established) to 1963, Kunqu Opera was altered a lot to function as a propaganda tool. The proclamation in 2001 was an important turning point, since then, the opera has been increasingly collecting attention from all over the world. What's more, Chinese government also established several policies to protect this art, among them was the National Operational Plan for the Program of Rescuing, Protecting and Supporting Kunqu Opera (国家昆曲艺术抢救、保护和扶持工 程实施方案) declared in 2005 , a policy to protect the art countrywide for the first time. Nevertheless, the protection policy in Chinese mainland is focusing on the creating of new works, rather than rescuing traditional ones tending to extinction (Qian, 2001), or recovering the opera's tradition that has been losing particularly since 1940s.

Contrary to Chinese mainland, Taiwan has been trying to retain Kunqu Opera's tradition of 1930s since 1940s. Although Kunqu Opera once existed in Taiwan not later than 18th century (Hung, 2000), related activities disappeared in 19th century (Chang, 2004). In 1940s, the arrival of amateur artists revived the opera. Owing to the martial law declared by Kuomintang-led government, Taiwan was isolated from Chinese mainland between 1949 and 1987, since then, Kunqu Opera developed in two dissimilar ways. Taught and affected by these amateur artists immigrated from Chinese mainland, students cherish the art's style of 1930s as well, which helps to create an atmosphere to retain and recover the tradition of this intangible cultural heritage as much as possible. Amid plenty of relevant groups now, Shuimo Kun Opera Troupe (水磨曲集昆剧团) is a typical one which was set up in 1987 as the first Kunqu Opera Troupe since 1940s in Taiwan. To compare Shuimo Kun Opera Troupe's performing style with the troupes from Chinese mainland can find the differences of Kunqu Opera evolving in divergent social environments, and to find the similarities as core factors of transmitted cultural values. In this research, the scene "Broken Bridge" (断桥) is chosen as an example.

Since intangible cultural heritage is a kind of living heritage, changing is inevitable. However, there are some rules within it which should be cherished as cultural values of the heritage. Obeying these rules can guarantee healthy development of living heritages, and their long-term existence. However, the rules are still under discussion at this time, which directly hinders the understanding of severity of Kunqu Opera's transmission problems, and the construction of a scientific protection system for this art. What's more, as Kunqu Opera is the most exquisite and complicated opera in China, its protection system can provide a model for other ones.

By taking advantage of the findings of this research as a base, a system can be constructed to assess present situation of Kunqu Opera accurately to each play; the system can also help to measure and record the changes happening to the heritage. Thus effective protection policy can be expected.

\section{Literature Review}

The majority of the research about Kunqu Opera usually focuses on its history, literature and music. Studies of how to protect this art mostly set their sights on the relationships between Kunqu Opera and a variety of stakeholders, on the methods to permeate the recondite art to the public, and its connection to culture industries.

A research conducted by $\mathrm{Wu}(2009)$ analysed the popularity among the public of new versions of two traditional Kunqu Opera works, pointed out that the moderate innovation was essential for this heritage in music, stage set, costumes and so on to keep up with the times, and emphasized the importance of loyalty to established scripts. Cheng (2016) claims the spirit within Kunqu Opera as its authenticity should be maintained during its evolution, however, the social environment nowadays can not breed wonderful scripts, and some performing traditions have long been ignored, therefore, the inheritance and modern interpretation of traditional scenes of Kunqu Opera are enough.

A research undertaken by Qian (2011) analysed merits and flaws to Kunqu Opera when more political and economic elements intervened nowadays in its transmission, concluded that to nurture new audience's appreciation ability was a method reliable in the long run. Bao (2017) investigated Kunqu Opera courses as a part of general education in colleges over the last few years, and emphasized the significance of diversity of related teachers, furthermore, the practice of knowledge and skills learned in class.

Tao (2016) revealed advantages and disadvantages of the application of digital media technologies, especially data visualization technologies applied on stage and social media technologies applied in the popularity of Kunqu Opera, admitted excessive utilization of these technologies on stage distracted audiences from performing, which also lowered Kunqu Opera's position to a kind of ornament, but approved the achievements in promoting access to this art. Xu and Huo (2019) analyse tourists' comments of Kunqu Opera tourism products on the website of Ctrip, 
China's largest online travel agency, find a big gap between related products and tourists' needs and advise reorganization of Kunqu Opera's current tourism resources.

The desire of these researches is to push the integration of Kunqu Opera into modern society, but the specific parts with cultural values of this art as a heritage remains unclear, which will be discussed in this paper.

\section{Method}

\subsection{Literature Study}

Literature study was made from books, journal and so on to supplement the information about Kunqu Opera in Chinese mainland and Taiwan, particularly the different social environments then. Studies about each factor of Kunqu Opera are also helpful to deepen the understanding of this art. As spoken language, melody, literary form of lyrics and dance are deemed as the key factors of this heritage, and stage set and costumes are easy to reflect the trends of times, information about these factors were collected more. Especially, Xie (2015) analysed several versions of Chinese mainland's Kunqu Opera scenes, which belong to different historical periods, on performance, literature, music and so on, and claimed that it was a constantly growing art and still far from perfection. Zhou (2019) compared differences between Chinese mainland's Hunan and Suzhou's Kunqu Opera on contents, singing, performance and so on, emphasized the attractive characteristics of Hunan's Kunqu Opera. However the core factors with cultural values of Kunqu Opera remain unclear.

These researches mainly employed qualitative comparison analysis method, so that the accuracy of differences is not sure. For an intangible cultural heritage, changing is inevitable. Nevertheless, if the changing obeys some rules to a large degree, in other words, not far from these rules, then these rules can be seen as the core factors of this heritage. Particularly, the comparison of the same intangible cultural heritage developing in different social environments can distinguish the core factors more clearly.

In consideration of the weakness of qualitative comparison analysis, in this research, factor-based quantitative comparison analysis will be applied to judge the core factors of Kunqu Opera. This is an empirical research method, which extracts some observable key factors from an object, and compares the accuracy of the factors' differences between the changed objects with divergent backgrounds via statistical techniques. Through the analysis, the degree of changing can be distinguished, so that the slightly changed factors can be deemed as core factors.

\subsection{Site Survey}

Field work were conducted three times in total in Chinese mainland and Taiwan during 2018 and 2019 to collect materials about Kunqu Opera troupes and the scene "Broken Bridge". To interview with relevant people, including artists, experts, among other interviewees, is also pivotal to comprehend the changes happened to Kunqu Opera and the reasons. Specifically, visits were paid to Suzhou Kunqu Opera Theatre of Jiangsu Province (江苏省苏州 昆剧院) and Kunqu Opera Museum of China (中国昆曲博物馆) in Suzhou City in September, 2018. The visits to Shuimo Kun Opera Troupe (水磨曲集昆剧团) and National Taiwan Normal University Department of Chinese (国立台湾师范大学国文系) in Taipei City were paid in October, 2018. Another visit to Humanities Center at National Central University (国立中央大学中国文学系) in Taoyuan City of Taiwan was conducted in August, 2019.

Books like Chinese Mainland's Theatre Reform (中国大陆的戏曲改革), published by the Chinese University of Hong Kong in 1969, and The Collection of Yu Zhenfei's Discussion on Art (俞振飞艺术论集), published by Shanghai Literature and Art Publishing House in 1985 are used in this research.

\subsection{Data Analysis}

Kunqu Opera's six factors of spoken language, melody, literary form of lyrics, dance, stage set and costumes will be analysed separately. The scene “Broken Bridge" of Shanghai Kunqu Opera Troupe (上海昆剧团) from Chinese mainland is chosen as a subject to compare with the one of Shuimo Kun Opera Troupe from Taiwan. Because Shanghai Kunqu Opera Troupe's version of "Broken Bridge" is a typical example reflecting the influence of social ideology especially in 1950s. It is a version adjusted during joint performance of artists Mei Lanfang (梅兰芳) and Yu Zhenfei (俞振飞) from 1930s to 1950s. The fundamental changes happened after the establishment of the People's Republic of China (1949), as a result to cater to social ideology such as anti-feudalism then. As Yu Zhenfei was the first head of Shanghai Kunqu Opera Troupe, the troupe was taught with the changed performance which we can see until now. In contrast with Shanghai's version, Taiwan's version, which shows respect for 1930s' style, was less influenced by social ideology, just as the performance we can see in Shuimo Kun Opera Troupe's version. So the differences between the two versions are distinct. What's more, related information is complete comparatively. 
DVDs in the attachment of the book Euphony-Xu Yanzhi, Zhang Shanxiang's Career in Kunqu Opera (芘壇清音 徐炎之、張善薌的芘曲生涯), which records the performance of Shuimo Kun Opera Troupe, are used in this research, as well as the Chengyun Music Scripts (承允曲谱) provided by the troupe. Furthermore, Chinese mainland's Zhenfei Music Scripts (振飞曲谱), which is used by Shanghai Kunqu Opera Troupe (上海昆剧团), and open access (https://www.bilibili.com/video/av48353514/; https://www.bilibili.com/video/av21295238/) to the records of the troupe's performance are adopted.

\section{Introduction of Zhezi Xi (折子戏) and the Scene "Broken Bridge"}

In the middle of Qing dynasty, competing with other operas, especially Peking opera, Kunqu Opera artists selected some popular scenes from the whole scripts to attract audience. As being performed frequently, these scenes, known as Zhezi Xi (折子戏), became masterpieces perfect in singing, dancing, and speaking (Wu, 2011, p. 123). Among them is the scene "Broken Bridge", which is from the script Leifeng Pagoda (雷峰塔), also known as the Legend of the White Snake, telling a love story between a white snake spirit Bai Suzhen (白素贞) and an ordinary person Xu Xian (许仙).

Speaking of the version from Chinese mainland in this research, the video record of Shanghai Kunqu Opera Troupe's performance in 1980 was selected, which is a widely accepted version by audience then as a masterpiece adapted by leading artists Mei Lanfang (梅兰芳) and Yu Zhenfei (俞振飞). And it was performed as a part to celebrate the 60th anniversary of Yu Zhenfei's art life, so it can reflect the changed style well.

When it comes to the version from Taiwan, since the members of Shuimo Kun Opera Troupe inherit the style learned from those amateur artists who immigrated to Taiwan in 1940s, and try to keep the style till now, this research chose the version in 2014, published as a part of attachment in the book Euphony- Xu Yanzhi, Zhang Shanxiang's career in Kunqu Opera (諧壇清音——徐炎之、張善薌的諧曲生涯) in 2018.

What's more, Taiwan and Chinese mainland were isolated from each other in 1980, so it is possible to see two patterns of the same scene existing in two dissimilar social environments.

\section{Background and Original Storyline of the Scene "Broken Bridge"}

After the white snake spirit Bai Suzhen (白素贞) and ordinary person Xu Xian (许仙) get married, a Buddhist monk Fahai (法海) from Jinshan Temple (金山寺) intends to kill Bai Suzhen, so he lures Xu Xian to Jinshan Temple as a part of his plan. In order to take Xu Xian home, Bai Suzhen and her younger sister Xiaoqing (小青), a green snake spirit, rush to Jinshan Temple and fight with Fahai, but fail and escape to the Broken Bridge over West Lake (西湖).

In Taiwan's version, after Bai Suzhen and Xiaoqing leave the stage, Xu Xian and Fahai appear together on the stage. This time, Fahai sends Xu Xian to a city called Linan (临安). After telling Xu Xian how to deal with Bai Suzhen the next, Fahai leaves. When Bai Suzhen meets Xu Xian, she reproaches him while expresses love for him. After a while, they make it up and leave together.

In order to facilitate the analysis, the scene, which is more than 30 minutes, is divided into four sections according to the storyline and characters on the stage.

Section 1: the debut of Bai Suzhen and Xiaoqing.

Section 2: the debut of Xu Xian.

Section 3: Bai Suzhen and Xiaoqing's chase after Xu Xian.

Section 4: the meeting of Bai Suzhen, Xiaoqing and Xu Xian.

\section{Analyses of Six Factors of the Scene "Broken Bridge"}

\subsection{Spoken Language}

As Kunqu Opera was born in Suzhou (苏州) area, a reformed Suzhou dialect was used as its spoken language at the very beginning, and Taiwan's artists have been keeping this tradition till now. In Chinese mainland, Kunqu Opera has spread almost over the whole area. Although the original spoken language can be heard in the Suzhou Kunqu Opera Theatre (江苏省苏州昆剧院), Kunqu Opera Theatre of Jiangsu Province (江苏省昆剧院) and Shanghai Kunqu Opera Troupe sometimes, since troupes of other cities want to adjust this art to indigenous audiences' tastes, the original spoken language is changed. For example, the Northern Kunqu Opera Theatre (北 方昆曲剧院), a troupe located in Beijing, chooses a spoken language similar to that in Peking opera; the Kunqu Opera Troupe of Hunan Province (湖南省昆剧团) reformed its spoken language based on Chenzhou (椰州) dialect. As the spoken language of Kunqu Opera varies across Chinese mainland, it is not the core factor of Kunqu Opera. 


\subsection{Melody}

Since there are still no quantitative benchmarks to tell if a melody is kunqiang, and the scene selected in this research is a traditional one with established music scripts, comparison of the scripts of Taiwan and Chinese mainland is conducted to make the yes or no judgement. Taiwan's Chengyun Music Scripts (承允曲谱), a revised one first published in 1972, and Chinese mainland's Zhenfei Music Scripts (振飞曲谱), first published in 1982, are the subjects. Chengyun Music Scripts has been used by Taiwan's Shuimo Kun Opera Troupe till now. And Zhenfei Music Scripts is used by Chinese mainland's Shanghai Kunqu Opera Troupe. Taking artists' creativity into account, if majority of the melody of "Broken Bridge" from Chinese mainland's Zhenfei Music Scripts is similar to Taiwan's Chengyun Music Scripts, kunqiang is judged as unchanged. The analyses are separated into musical notes and rhythms. Since both versions share the same metre, the analysis of metre is not done.

Table 1. Comparison of Main Musical Notes in Bars between Chinese Mainland and Taiwan's Versions of the Scene "Broken Bridge"

\begin{tabular}{lcccc}
\hline & Section 1 & Section 2 & Section 3 & Section 4 \\
\hline Number of Bars & 53 & 86 & 61 & 106 \\
Same Bars & 45 & 70 & 54 & 78 \\
Similarity & $85 \%$ & $81 \%$ & $89 \%$ & $74 \%$ \\
\hline Note.
\end{tabular}

Note. The scene is divided into four sections according to the storyline and characters on the stage. In the comparison of musical notes between the two versions, change (increase or decrease) of music rest is neglected. In section 2, the version of Chinese mainland has one more bar than Taiwan's version, since the bar is the repetition of the one immediately before, in this research the bar is neglected.

Table 2. Comparison of Rhythms in Bars between Chinese Mainland and Taiwan's Versions of the Scene "Broken Bridge"

\begin{tabular}{lcccc}
\hline & Section 1 & Section 2 & Section 3 & Section 4 \\
\hline Number of Bars & 53 & 86 & 61 & 106 \\
Similar Bars & 51 & 74 & 44 & 96 \\
Similarity & $96 \%$ & $86 \%$ & $72 \%$ & $91 \%$ \\
\hline
\end{tabular}

Note. "Similar Bars" means more than 50\% (not including 50\%) of rhythms between the two versions are the same.

Table 3. Lines with Changed Contents and Unchanged Number of Words in Chinese Mainland and Taiwan's Versions of the Scene "Broken Bridge"

\begin{tabular}{|c|c|c|}
\hline & Taiwan's Version & Chinese Mainland's Version \\
\hline 1 & 奴薄命孤变照命 & 空幸负海誓山盟 \\
\hline 2 & 锦层层足踏翠云 & 锦层层过眼烟云 \\
\hline 3 & 虚飘飘飞下琼琚境 & 虚飘飘魂断蓝桥境 \\
\hline 4 & 寻思教我两下分如并 & 寻思教我两下分复并 \\
\hline 5 & 痛遭魔心暗惊 & 痛往事暗伤情 \\
\hline 6 & 遥观妖魔到 & 遥观青儿到 \\
\hline 7 & 哪知豹狼心性 & 哪知狠毒心性 \\
\hline 8 & 我这里急忙追奔 & 我这里疾忙追奔 \\
\hline 9 & 我向前向前时心中战兢 & 我向前向前时心内战兢 \\
\hline 10 & 娘行见慈心望垂情 & 娘行鉴此心望垂情 \\
\hline 11 & 區耐他言忒厉狠 & 匜耐他言忒利狠 \\
\hline 12 & 教人怎不心儿惊 & 教人怎不心儿警 \\
\hline 13 & 烦伊劝解 & 烦你劝解 \\
\hline 14 & 只恨我命犯迍邅遇恶僧 & 只恨你恩怨不明遇恶僧 \\
\hline
\end{tabular}

Note. Lyrics are different in 18 lines altogether between the two versions. The number of words is different in 4 lines with an added word in them respectively in Chinese mainland's version. In this research, the comparison focuses on the other 14 lines, which have changed contents but unchanged number of words. The specific changed contents are underlined in Table 3. 
According to Table 1, proportions of bars sharing the same main musical notes in whole four sections are more than $70 \%$, the same as rhythms in the entire four sections showed in Table 2, therefore, the melody kunqiang of scene "Broken Bridge" is judged as unchanged. As this factor is not changed over time in different social environments, kunqiang is one core factor of Kunqu Opera.

\subsection{Literary Form of Lyrics}

Table 4. Comparison of Rhymes of Lines with Changed Contents and Unchanged Number of Words between Chinese Mainland and Taiwan's Versions of the Scene "Broken Bridge"

\begin{tabular}{cccc}
\hline & Taiwan's Version & Chinese Mainland's Version & Result \\
\hline 1 & $\mathrm{G}$ & $\mathrm{G}$ & Same \\
2 & $\mathrm{Z}$ & $\mathrm{Z}$ & Same \\
3 & $\mathrm{G}$ & $\mathrm{G}$ & Same \\
4 & $\mathrm{G}$ & $\mathrm{G}$ & Same \\
5 & $\mathrm{G}$ & $\mathrm{G}$ & Same \\
6 & $\mathrm{Y}$ & $\mathrm{Y}$ & Same \\
7 & $\mathrm{G}$ & $\mathrm{G}$ & Same \\
8 & $\mathrm{Z}$ & $\mathrm{Z}$ & Same \\
9 & $\mathrm{G}$ & $\mathrm{G}$ & Same \\
10 & $\mathrm{G}$ & $\mathrm{G}$ & Same \\
11 & $\mathrm{Z}$ & $\mathrm{Z}$ & Same \\
12 & $\mathrm{G}$ & $\mathrm{G}$ & Same \\
13 & $\mathrm{~J}$ & $\mathrm{~J}$ & Same \\
14 & $\mathrm{G}$ & $\mathrm{G}$ & Same \\
& & & $100 \%$ \\
\hline
\end{tabular}

Note. "G" means the rhyme geng (庚); "Z" means the rhyme zhen (真); "Y" means the rhyme yao (爻); "J" means the rhyme jie (皆). The judgements of rhymes are based on Hongwu Rhymes (洪武正韵).

Table 5. Comparison of Tone Patterns of Lines with Changed Contents and Unchanged Number of Words between Chinese Mainland and Taiwan's Versions of the Scene "Broken Bridge"

\begin{tabular}{|c|c|c|c|}
\hline & Taiwan's Version & Chinese Mainland's Version & Similarity \\
\hline 1 & $-1 /--1 /$ & $--/ / /--$ & $29 \%$ \\
\hline 2 & $/--/ / /-$ & / - - - - - & $71 \%$ \\
\hline 3 & $---1--1$ & $---1--1$ & $100 \%$ \\
\hline 4 & $---/ / / \ldots$ & $---/ / /-/-$ & $89 \%$ \\
\hline 5 & / - - - / - & $1 / / /--$ & $33 \%$ \\
\hline 6 & ---1 & ---1 & $100 \%$ \\
\hline 7 & $-\ldots-1$ & $--1 /-1$ & $67 \%$ \\
\hline 8 & $/ / / /--$ & $/ / / /--$ & $100 \%$ \\
\hline 9 & $1 /-1---1-$ & $1 /-1---1 /-$ & $90 \%$ \\
\hline 10 & - - $_{-1}-\ldots$ & $--/ / \ldots$ & $88 \%$ \\
\hline 11 & $/ /--/ / /$ & $1 /--/ / /$ & $100 \%$ \\
\hline 12 & $--1-\ldots$ & $--1--1$ & $86 \%$ \\
\hline 13 & $--/ /$ & $-1 / 1$ & $75 \%$ \\
\hline 14 & $-/ / / /--1--$ & $-/ /-\ldots-1--$ & $80 \%$ \\
\hline
\end{tabular}

Note. “"” means level tone (平); “” means oblique tone (入). The judgements of tone patterns are based on Zengguang Poetic Rhymes Collection (增广诗韵集成).

The literary form of lyrics of Kunqu Opera is deemed as qupai style (曲牌体). A style embodied in a number of sets of rules which stipulate the number of lines and words in them, as well as rhymes, tone patterns (level and oblique tones 平入) and so on. In the scene "Broken Bridge", the number of lines is not changed. Speaking of the number of words in each line, four lines were changed by adding a word in them respectively, since the added words are in the places allowing adding, these lines are deemed as according with the rules of qupai style, so that their changes are not discussed in this research further. The analysis focuses on rhymes and tone patterns of lines 
with changed contents and unchanged number of words. If majority of rhymes and tone patterns are not changed, the qupai style is judged as unchanged.

Table 4 shows that even though some contents are changed in a few lines, the rhymes are not changed. Furthermore, as can be seen in Table 5, despite line 1 and line 5, the majority (12/14, namely $86 \%$ ) of the changed lines are basically sharing the same tone patterns. Therefore, the lyrics' literary form, known as qupai style, of the scene "Broken Bridge" is judged as unchanged. As this factor remained over time in divergent social environments, qupai style is one core factor of Kunqu Opera.

\subsection{Dance}

As masterpieces, Zhezi Xi has been performed and polished repeatedly, so the dance in each scene is fixed comparatively and considered as an important factor. However, in order to cater to social ideology in Chinese mainland, especially after 1949, some adjustments were made. For example, as Fahai (法海) was deemed as a symbol of feudalism, his appearance was cancelled in section 2, as well as the dancing of this part (Yu \& Wang \& $\mathrm{Xu}, 1985, \mathrm{p} .103)$. In this research, the comparison of the dance in two versions of the scene "Broken Bridge" will be conducted, in order to judge if this factor was changed largely over time.

Actor's lines comprise singing and speaking, they are considered to have close connection with dancing. Artists are always dancing while singing or speaking. However, speaking is not regulated strictly, improvisation is acceptable, as well as the dancing connected with it. So in this research, the dance relating to speaking is not discussed. What's more, 18 lines with changed lyrics are not discussed, neither.

Assessment includes three levels based on changes' degrees. The change of moving routes or performers' relative location is defined as the largest difference, because dance will also change simultaneously and obviously. The apparent change of dance with the same moving routes and performers' relative location is defined as the middle level. The slight or no change of dance is defined as identical dance.

Table 6. Similarity of Dance between Chinese Mainland and Taiwan's Versions of the Scene "Broken Bridge"

\begin{tabular}{|c|c|c|c|c|c|c|c|c|}
\hline \multicolumn{3}{|c|}{ Section 1} & \multicolumn{2}{|l|}{ Section 2} & \multicolumn{2}{|l|}{ Section 3} & \multicolumn{2}{|l|}{ Section 4} \\
\hline & Line & Same & Line & Same & Line & Same & Line & Same \\
\hline 1 & 顿然间驾㚗折颈 & 0 & 一程程钱塘相近 & 0 & 轻分变镜 & 1 & 曾同变凤衾 & 1 \\
\hline 2 & 好教人泪珠暗滚 & 0.5 & 蓦过了千山万岭 & 0 & 思量到此教人恨 & 0 & 指望交鸳颈 & 1 \\
\hline 3 & 怎知他一旦多薄幸 & 0.5 & 只怕怨雨愁云恨未平 & 0 & 全不念凤枕变衾 & 0 & 不记得当时曾结三生证 & 1 \\
\hline 4 & 忒硬心 & 0.5 & 追省 & 1 & 谁知今朝绝恩情 & 1 & 如今负此情反背前盟 & 0 \\
\hline 5 & 怎不教人两泪零 & 0 & 感垂怜相救恩 & 0 & 教人不觉添悲哽 & 0.5 & 你听信㭸言忒硬心 & 0 \\
\hline 6 & 无端抛闪抛闪无投奔 & 0 & 伤心 & 0.5 & 哪哪怕他插翅飞腾 & 0.5 & 追思此事真堪恨 & 0 \\
\hline 7 & 凄清 & 0 & 我双眼定睛 & 0.5 & 我行步紧 & 0 & 不觉心儿气满襟你真薄幸 & 0.5 \\
\hline 8 & 不觉的变凤分 & 0 & 忽听她言 & 0.5 & 愿苍天赐救星 & 1 & 你缘何屡屡起狼心 & 0 \\
\hline & 伤心 & 0 & 相叫声声 & 0.5 & 止不住珠泪盈盈 & 0.5 & 害得我几丧残生进退无门 & 0.5 \\
\hline & 怎能够再和鸣 & 0 & 苍天怜悯 & 1 & 止不住珠泪盈盈 & 0 & 怎不教人恨 & 0 \\
\hline 11 & & & 更没处将身遮掩 & 1 & 笑伊行何处行 & 1 & 娘行须三省 & 0 \\
\hline 12 & & & 怎得天相救 & 0 & 笑伊行何处行 & 1 & 乞望生怜悯 & 0.5 \\
\hline 13 & & & 这灾星 & 0 & & & 感你恩情我指望偕欢庆 & 0 \\
\hline 14 & & & 我暂时拼命向前行 & 0 & & & 听他一划胡言几作变凤分 & 0 \\
\hline 15 & & & & & & & 望海涵命 & 0 \\
\hline 16 & & & & & & & 暂息雷霆容赔罪生欢庆 & 0 \\
\hline 17 & & & & & & & 此行休得泄真情 & 0.5 \\
\hline 18 & & & & & & & 两下里又生欢庆 & 0.5 \\
\hline & Sectional Similarity & $15 \%$ & & $36 \%$ & & $54 \%$ & & $31 \%$ \\
\hline
\end{tabular}

Note. "Same 0" means moving routes or performers' relative location is obviously changed. "Same 0.5 " means although moving routes and performers' relative location are the same, dance is obviously different. "Same 1" means moving routes or artists' relative location is the same, and the dance is the same or only slightly different. Sectional Similarity = the sum of "same" of each section / the number of lines of each section 
Translation of lyrics in Table 6:

Section 1: line 1. suddenly we separated from each other; line 2. my teardrops are running silently; line 3 . how could I know his heartlessness; line 4. what a stony heart; line 5. how could I stop my weep; line 6 . I do not know where to go; line 7. I am so desolate; line 8. we separated from each other unexpectedly; line 9. so sad; line 10. how can we reunite?

Section 2: line 1. we are approaching the Qiantang River; line 2. we crossed over mountain after mountain; line 3. what I am afraid of is the continued sadness and hatred; line 4. I examine my own conscience; line 5. I appreciate your help to save me; line 6. I am so sad; line 7. I fix my eyes upon there; line 8 . I heard her voice abruptly; line 9. her calling is continuing; line 10. my goodness, could you help me; line 11. there is no place to hide; line 12. who can help me; line 13. what a star of calamity; line 14. I just go ahead quickly.

Section 3: line 1. we couple just broke up so easily; line 2. I just hate when I think about it; line 3. you do not care about our love completely; line 4. how could I know we broke up now; line 5. I just could not help to be sad; line 6. even if he has feathers to fly; line 7. I go ahead fast; line 8. my goodness, could you please help me; line 9 . I could not help to cry; line 10. I could not help to cry; line 11. where are you going; line 12. where are you going?

Section 4: line 1. we were a couple loving each other; line 2. I hoped that we love deeply; line 3. do you still remember your promise; line 4. but now, you just betrayed your promise; line 5. you are so stony-hearted to hear and believe slanders; line 6. I just hate when I rethink about it; line 7. you are so stony-hearted that my heart is full of anger; line 8. why do you always hurt me; line 9 . I nearly lost my life just because of you; line 10 . how could I stop hating you; line 11. could you please consider the thing again; line 12. I beg for your mercy; line 13. thank you for your love and I am also hoping we live happily; line 14. we nearly broke up completely due to the monk's slanders; line 15. please forgive me; line 16. in order to reconcile, please do not be angry any more and listen to my apologies; line 17. this time we should not expose our emotions; line 18. well, they just reunited.

Table 6 shows that only section 3 keeps major dance as a sharing part between the two versions, however, the sectional similarity is just over 50\%. The other three sections hold sectional similarity numbers below $40 \%$. Since the majority of dance in the scene "Broken Bridge" is different between the two versions, dance is judged as a changed factor. Therefore, dance is not the core factor of Kunqu Opera.

\subsection{Stage Set}
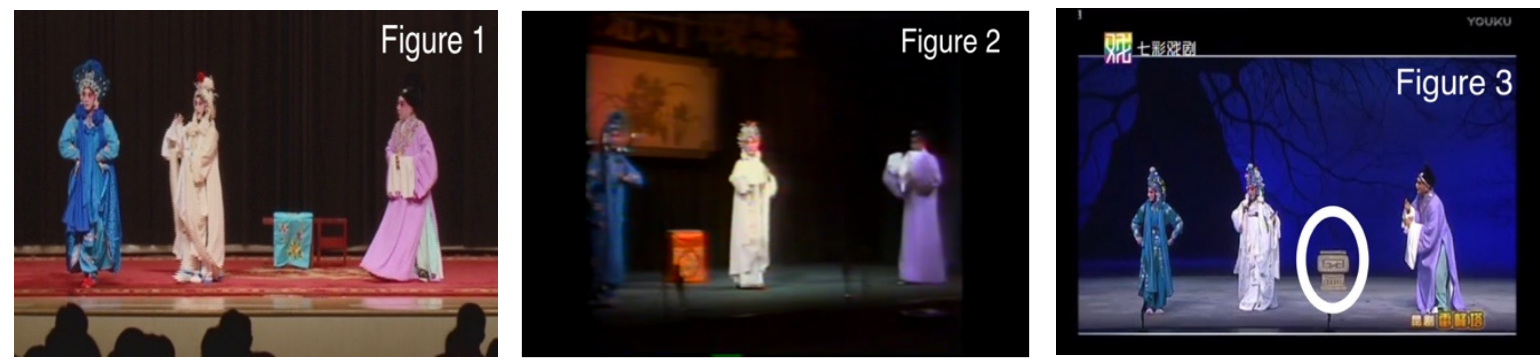

Figure 1. Taiwan's version in 2014 performed by Shuimo Kun Opera Troupe, a screenshot from the attachment video of the book Euphony- Xu Yanzhi, Zhang Shanxiang's career in Kunqu Opera (崑壇清音——徐炎之、 張善薌的崑曲生涯)

Figure 2. Chinese Mainland's version in 1980 performed by Shanghai Kunqu Opera Troupe, a screenshot from the source https://www.bilibili.com/video/av48 353514/
Figure 3. Chinese Mainland's version later than 1987 performed by Shanghai Kunqu Opera Troupe, a screenshot from the source https://www.bilibili.com/video/BV1 1W411 M7LW?from=search\&seid= 5240413052924148736

Since the late Qing dynasty (1840-1912), performer-centred system in Chinese traditional opera was already formed. Each stage set serves the needs of performers, which means helping to channel audiences' attention into artists' performance, rather than eclipsing it. Thus the stage set, no matter stage backgrounds or stage equipment, was made as simple as possible (Zhou, 2016, p. 54). Speaking of stage backgrounds, one piece of one-colour curtain was often applied. When it comes to stage equipment, in the ordinary way, one table and two chairs was always given the preference. The meanings of tables and chairs on stage are not limited, they can also be the 
symbols of a mountain, a bridge, a stone and so on (Ding, 2014, p. 21). Artists' performance helps to stimulate audiences' imagination of the atmosphere on stage. In other words, Chinese traditional opera is impressionistic. In Taiwan's version, this tradition is preserved loyally (Figure 1). In Chinese mainland's version, stage background was changed to express the environment of the scene "Broken Bridge" (Figure 2). A version later from the same troupe even changed the chair to a piece of stone-like equipment (Figure 3). This trend can date back to the theatre reform (戏曲改革 1949-1963), during which, opera was used as a tool of propaganda, and was injected with a lot of western theories and practices, such as realism and director-centred system (Sun, 2017). Pushing audience to understand a play's motif became more important than stimulating their aesthetic imagination. A conclusion can be made that stage set of Kunqu Opera is a changeable factor, and it is changing from impressionism to realism in Chinese mainland.

\subsection{Costumes}

Chinese traditional opera's costumes originated in Ming dynasty (Zhou, 2016, p. 40). As it evolves, especially in order to blur the sense of specific dynasty, some changes happened. For example, sleeves became longer and attached with long white extensions to the cuffs, which are called water sleeves (水袖); boots bottom became thicker; armour became a special coat called kaoshen (靠身) and so on (Sun, 1991). Comparing costumes between Chinese mainland and Taiwan (Figure 1,2 and 3), despite some slight changes in details and colours, the style of costumes is not changed. In other words, the style based on Ming dynasty is kept as a core factor in costumes of Kunqu Opera.

\section{Conclusion}

Although some factors of intangible cultural heritage are changing all the time, the evolution of this heritage is based on some core factors. In order to conduct effective protection of intangible cultural heritage, the grasp of core factors is essential. However, due to difficulties to record this heritage and inadequacy of related records, among other reasons, researches about inherited cultural values of the ever-changing heritage are not enough. In this research, Kunqu Opera was taken as an example, factor-based quantitative comparison analysis was applied to make the art's core factors clear. Specifically, the comparison of a Kunqu Opera's traditional masterpiece "Broken Bridge" was conducted between Taiwan's Shuimo Kun Opera Troupe and Chinese mainland's Shanghai Kunqu Opera Troupe in spoken language, melody, literary form of lyrics, dance, stage set and costumes. Taiwan's Kunqu Opera, which symbolizes a style of 1930s, and Chinese mainland's Kunqu Opera, whose style is changing unceasingly, share the same roots but evolve towards divergent directions as a result of isolation and recommunication of the two areas.

Through comparative analysis of the two styles of the scene "Broken Bridge", the melody kunqiang and the literary form of lyrics, known as qupai style, are not changed over time even in different social environments. In conclusion, kunqiang and qupai style are probably the core factors of Kunqu Opera. Specifically, more than $70 \%$ bars sharing the same main musical notes and rhythms in the scene's whole four sections between the two versions. It means that the melody kunqiang is not changed. What's more, all of the 14 lines with changed contents but unchanged number of words between the two versions are sharing the same rhymes. 12 out of these lines (about $86 \%$ ) basically sharing the same tone patterns. It means that the lyrics' literary form, namely qupai style, is not changed.

Moreover, according to the comparison of stage set in different versions of the scene "Broken Bridge" from different historical periods, the impressionistic and less designed stage set is gradually developing into realityimitated style in Chinese mainland. It means that realism as a trend in Kunqu Opera is developing continuously in Chinese mainland.

Speaking of the opera's costumes, based on the comparison of three different versions of the scene "Broken Bridge" from different historical periods, the general image, a style based on Ming dynasty, is remained, however, details are changing all the time, as well as the colours.

In view of the conclusion, effective protection of Kunqu Opera should lay stress on kunqiang and qupai style. Considered that Kunqu Opera is a kind of comprehensive art, every factor within it is connected with one another intricately, viewing this art as an organic whole with cores is important. In other words, systemic protection with key points is vital for Kunqu Opera's sustainable existing.

In this research, only one scene was analysed to reach the above conclusions. In order to make these conclusions more persuasive, analysis on a large-scale basis is necessary in the future.

\section{Acknowledgments}

This research is supported by the Overseas Study Tour Support Program provided by the University of Tsukuba, and "Jissen Women's Educational Institute Alumnae Group" private foundation scholarship as well. 


\section{Conflict of interests}

The authors declare that there is no conflict of interests regarding the publication of this paper.

\section{References}

Bao, K. K. 鲍开恺 (2017). On Kunqu Opera courses as a general education in colleges 关于高校昆曲通识教育 的思考. Data of Culture and Education, 752(12), 67-68\&91.

Chang, C. F. 張啟豐 (2004). Research about opera activities and development of Taiwan during Qing dynasty 清代台灣戲曲活動與發展研究 (Doctoral dissertation, National Cheng Kung University, Tainan, Taiwan). Retrieved from https://ndltd.ncl.edu.tw/cgi-bin/gs32/gsweb.cgi/ccd=MV_C4_/record?r1=1\&h1=4

Cheng, Y. 程艳 (2016). The evolving authenticity: Nature of Kunqu Opera's transmission and creation 演进中 的原真性：昆曲艺术传承与创新的本体. Opera Art 戏曲艺术, 37(4), 89-91.

Ding, X. X. 丁修询 (2014). Research on the dance of Kunqu Opera 昆曲表演学 (p. 21). Phoenix Education Publishing, Ltd.

Hung, W. C. 洪惟助 (2000). Taiwan's Kunqu Opera activities and communication with Chinese mainland 台灣 的芘曲活動與海峽兩岸的崑曲交流. Proceedings of the Seminar on the Review and Prospect of Opera Across the Strait 兩岸戲曲回顧與展望研討會論文集 (pp. 24-33). Yilan: Preparatory Office of the National Headquarters of Taiwan Traditional Arts.

Hung, W. C. 洪惟助 (2002). Kunqu Opera dictionary 崑曲辭典. National Center for Traditional Arts.

Lin, C. Y. 林佳儀 (2018). Euphony- Xu Yanzhi, Zhang Shanxiang's career in Kunqu Opera 崑壇清音——徐炎 之、張善薌的崑曲生涯. Showwe Information Co., Ltd.

Qian, Y. P. 钱永平 (2001). Research on the protection of Kunqu Opera in the heritage context 遗产化境域中的 昆曲保护研究. Cultural Heritage, (2), 26-35.

Sun, L. H. 孙立慧 (1991). On the basic features of traditional Chinese opera costumes 论中国传统戏曲服饰的 基本特征. Opera Art 戏曲艺术, (2), 85.

Sun, M. 孙玫 (2017). Modern Chinese intellectuals and theatre reform. Hundred Schools in Arts, 156(3), 18.

Tao, L. Y. 陶蕾伃 (2016). On merits and flaws of digital media in the development and popularity of Kunqu Opera 浅论数字媒体技术对昆曲发展与传播的利与弊. Home Drama, 234(9), 31-32.

Wu, X. L. 吴新雷 (2009). The transmission and development of Kunqu Opera nowadays 当今昆曲艺术的传承 与发展一一“苏昆”青春版《牡丹亭》到“上昆”全景式《长生殿》. Literature \& Art Studies, (6), 71-77.

Wu, X. L. 吴新雷 (2011). Introduction to Kunqu Opera 昆曲艺术概论. Shanxi Education Press.

Xie, Y. F. 解玉峰 (2005). On the preservation of Kunqu Opera as a cultural heritage 也谈中国昆曲作为“文化 遗产”的保存问题. Theatre Arts 戏剧艺术, (1), 52-61.

Xu, X., \& Huo, J. Q. 许金金\&霍佳婧 (2019). Research on intangible cultural heritage information resource organization oriented to cultural tourism - taking Kunqu Opera as an example. Library Tribune, (1), 33-39.

Yu, Z. F., Wang, J. X., \& Xu, Y. (1985). The collection of Yu Zhenfei's discussion on art 俞振飞艺术论集 (p. 103). Shanghai Literature and Art Publishing House.

Zhao, C. 赵聪 (1969). Chinese Mainland's Theatre Reform 中国大陆的戏曲改革. Chinese University of Hong Kong.

Zhou, Q. 周秦 (2019). Respective merits of wu songs and chu dances: A discussion on the aesthetic features of. xiang-kun arts 吴歌楚舞各千秋——谈湘昆艺术的审美特征. Journal of Suzhou University of Science and Technology (Social Science) 苏州科技大学学报(社会科学版), (1), 58-62.

Zhou, Y. B. 周贻白 (2016). The history of Chinese theatre 中国剧场史. China Theatre Press.

\section{Copyrights}

Copyright for this article is retained by the author(s), with first publication rights granted to the journal.

This is an open-access article distributed under the terms and conditions of the Creative Commons Attribution license (http://creativecommons.org/licenses/by/4.0/). 